\title{
BAKSO SAPI IKAN KEMBUNG SEBAGAI ALTERNATIF JAJANAN SEHAT TINGGI PROTEIN UNTUK ANAK SEKOLAH DASAR
}

\author{
Diah Ratnasari*1 ${ }^{\text {,Dyah Kartika Wening }}{ }^{2}$, Yuniarti Dewi ${ }^{3}$,Ragilia Nurul Qomariyah ${ }^{4}$ \\ 1,3,4 Prodi Ilmu Gizi, Fakultas Ilmu Kesehatan, Universitas Muhadi Setiabudi, Indonesia \\ ${ }^{2}$ Program Studi Gizi, Fakultas Ilmu Kesehatan, Universitas Ngudi Waluyo, Indonesia \\ *e-mail: ${ }^{1}$ diahratna1708@gmail.com
}

\begin{abstract}
ABSTRAK
Ikan kembung bisa dikenal dengan sebutan sebagai mackarel fish yang termasuk ikan dengan harga yang murah. Ikan kembung itu rasanya enak dan gurih karena kaya akan gizi di antaranya protein dan omega-3. Penelitian ini bertujuan untuk melihat pengaruh substitusi daging sapi dengan ikan kembung dalam pembuatan bakso terhadap daya terima, kadar protein dan kadar air. Jenis penelitian termasuk metode eksperimental dengan satu faktor yang di coba, yaitu Daging sapi dengan substitusi Ikan Kembung yang terdiri dari 3 perlakuan dengan proporsi 80\%:20\%,60\%:40\%, 40\%:60\%. penelitian yang akan dilaksanakan dengan menggunakan rancangan acak lengkap (RAL) dengan adanya tiga kali ulangan Pengambilan data menggunakan metode kuisioner. Uji statistik dengan menggunakan uji Anova. Hasil penelitian ini menunjukkan bahwa Kadar protein pada perlakuan P1, P2, P3 berturut-turut yaitu 11,62\%, 11,59\% dan $11,80 \%$ dan tidak berpengaruh nyata dimana nilai $\mathrm{p}=0,806$. Hasil uji hedonik menunjukkan bahwa aroma $(\mathrm{p}=0,001)$, warna $(\mathrm{p}=0,049)$ dan tekstur $(\mathrm{p}=0,048)$ berpengaruh nyata dimana nilai $\mathrm{p}<0,05$, sedangkan rasa $(\mathrm{p}=0,072)$ tidak berpengaruh nyata. Kesimpulan penelitian ini adalah tidak adanya pengaruh penambahan ikan kembung terhadap kadar protein dan rasa bakso ikan. Sedangkan substitusi ikan kembung berpengaruh terhadap aroma, warna dan tekstur.
\end{abstract}

Kata kunci: Bakso, Ikan kembung, Protein, Jajanan sehat

ABSTRACT

Bloated fish can be known as mackarel fish which includes fish at a cheap price. Bloated fish tastes good and savory because it is rich in nutrients including protein and omega-3s. The study aimed to look at the effect of beef substitution with bloated fish in meatball making on acceptableness, protein levels and water content. This type of research includes an experimental method with one factor tried, namely Beef with substitution of Bloated Fish consisting of 3 treatments with a proportion of 80\%:20\%, 60\%:40\%, 40\%:60\%. The research will be conducted using a complete random design (RAL) with three repeats of data retrieval using questionnaire methods. Test statistics using the Anova test. The results of this study showed that protein levels in the treatment of P1, P2, P3 were $11.62 \%, 11.59 \%$ and $11.80 \%$ and had no real effect on where the value of $p=0.806$. The results of this study showed that protein levels in the treatment of P1, P2, P3 were $11.62 \%, 11.59 \%$ and $11.80 \%$ and had no real effect on where the value of $p$ $=0.806$. Hedonic test results showed that scent $(p=0.001)$, color $(p=0.049)$ and texture $(p=0.048)$ had a noticeable effect where the value of $p<0.05$, while taste $(p=0.072)$ had no real effect. The conclusion of this study is the absence of the effect of the addition of bloated fish on protein levels and the taste of fish meatballs. While the substitution of bloated fish affects the aroma, color and texture.

Keywords: Meatballs, Bloated Fish, Protein, Healthy Snacks

\section{PENDAHULUAN}

Ikan kembung omega-3nya tiga kali lebih besar dari kandungan omega-3 ikan salmon[1]. Manfaat yang paling utama dari Omega-3 itu dapat memperbaiki kadar lemak pada tubuh sehingga memungkinkan terhindar dari adanya penyakit yang salah satunya adalah jantung koroner. Disini jika membahas Omega-3, siikan kembung yang merupakan ikan lokal di indonesia, kandungan gizinya $\mathrm{j}$ lebih banyak dari ikan yang lain. Dr Ir Diah M Utari M.Kes menurut beliau. Pada Ikan kembung terdapat 2,6 g Omega-3 sedangkan pada ikan salmon hanya 1,4 g. ahli gizi dari Fakultas ilmu Kesehatan Masyarakat Universitas Indonesia [2] Ikan Kembung adalah ikan air laut yang diperoleh pada musim musim puncaknya maret sampai juni.[3] 
Protein pada ikan kembung merupakan salah satu pilihan dibandingkan dengan ikan lokal yang direkomendasikan atau dianjurrkan untuk MPASI , selain kandungan DHA dan Omega-3 ikan kembung ini banyak vitaminnya dibutuhkan khususnya untuk pertumbuhan anak [4]. Dari kandungan vitamin B12, vitamin D, dan termasuk fosfor yang cukup tinggi hal ini merupakan Salah satu manfaat ikan kembung lainnya terutama untuk anak Sekolah Dasar [5]. Kadar Protein yang dimiliki oleh ikan kembung dari 100/gr mengandung 22.0 gr protein, Omega-3 , $20.0 \mathrm{mg}$ kalsium, energi 103,0 k, air 76.0 gr, vit A $30.0 \mathrm{mg}$ dan Vitamin B1 $0.05 \mathrm{mg}$ jadi ikan kembung sangat direkomendasikan untuk berkembang salah satunnya pada industri pangan.[6]biyasanya ikan kembng hanya dijadikan atau dikonsumsi sebagai lauk seperti olahan digoreng, dijadikan pepes, dibakar dikuah, dan masih banyak olahan olahan dari ikan kembung itu sendiri. Salah satu Penelitian yang sudah dilakukan tentang potensi ikn kembung adalah produk produk olahannya ikan kembung diantaranya ikan asin, peda ikan kembung, surimi tepung ikan kembung[7]. Sudah banyak penelitian-penelitian yang membahas aneka olahan lain misalnya camilan dari bahan dasar ikan kembung yang dibuat bakso[8].

Bakso adalah salah satu jenis jajanan atau makanan yang banyak disukai orang dewasa maupun anak, berbagai jenis bakso telah di kembangkan untuk menghasilkan bakso yang tidak hanya enak tetapi juga menyehatkan[9]. Akan tetapi saat ini belum banyak bakso dipasaran yang menggunakan ikan sebagai pengganti bakso selain proteinya yang tinggi harganya juga terjangkau, pada umumnya bakso yang beredar dipasaran yaitu bakso yang terbuat dari daging ayam memiliki kadar protein 25 gr dalam $85 \mathrm{gr}$, daging sapi 18,8 gr protein dalam 100 gr, atau daging ikan tengiri memiliki kadar protein 21,4gr dan kandungan protein ikan kembung sebsar 22,0 gr dalam 100 gr[10]. Penelitian ini sejalan dengan penelitian Cindy Nafa Ferantika (2015) "Karakteristik Fisiokimia Dan Uji Kesukaan Bakso Ikan Kembung (Rastrelliger kanagurta) dengan Substitusi Wortel" diketahui memakai bahan nya tepung wortel diperoleh penggunaan sebanyak $80 \% / 50 \%$ sebagai perlakuan terbaik terhadap sifat organoleptik dengan 5 perlakuan yang berbeda[11]. Mahasiswa Ilmu Teknologi Pangan (2013) "Karakteristik Organoleptik dan Kimia Bakso Ikan Kembung (Rastrelliger Kanaguarta) Yang di Substitusi dengan Tepung Sagu (Metroxylon sago) Sebagai Bahan Pengisi" fillerditambahkan pada taraf 20\% hasil yang terbaik pada kualitas kimianya sedangkan untuk penambahan fillernya pada taraf $10 \%$ hasilnya terbaik pada pengujian Organoleptik[12].

Anak Sekolah Dasar Penting untuk Asupan gizinya disamping makan-makanan pokok, Anak Sekolah Dasar juga sangat suka Jajan untuk itu Jajanan yang dipilih juga harus sehat dan bergizi. Peran penting Protein bagi perkembangan Anak berdasarkan Tabel Angka Kecukupan Gizi (AKG) 2013 anak-anak yang sedang tumbuh terutama di usia 1-3 tahun, membutuhkan asupan protein $26 \mathrm{gr}$ per hari, kebutuhan Protein semakin meningkat seiring bertambahnya usia, yaitu 35gr per hari anak usia 4-6 tahun, dan 49gr per hari untuk anak usia 7-9 tahun. Kekurangan asupan protein akan membuat anak mengalami gangguan pertumbuhan, gangguan kecerdasan, serta masalah perilaku[13]. Dengan menjadikan daging ikan kembung sebagai substitusi bakso sapi menggunakan daging ikan kembung yang telah difilet dan diblender serta di olahsebagai jajanan untuk anak Sekolah Dasar karena kandungan gizinya yang tinggi, diketahui bahwa ikan kembung memberikan sumbangan energi, protein, lemak tidak jenuh, kalsium, vitamin A, vitamin D, vitamin B6 yang baik untuk tumbuh kembang anak-anak. Hal ini bertujuan untuk menciptakan suatu produk jajanan baru yang mempunyai nilai gizi tinggi di buatlah produk olahan bakso yang belum ada di pasaran yang diperuntukan untuk anak-anak.

\section{BAHAN DAN METODE}

Jenis penelitian ini adalah eksperimental yaitu dengan satu faktor yang di coba, yaitu Daging sapi dengan substitusi Ikan Kembung yang terdiri dari 3 taraf yaitu 20\%, 40\%, 60\%, dengan rancangan percobaan yang digunakan dalam percobaan ini adalah rancangan acak lengkap (RAL),yang terdiri dari 3 perlakuan. Masing-masing perlakuan di ulang 3 kali pengulangan dengan demikian akan diperoleh 9 unit percobaan.Waktu dan tempat Penelitian dilaksanakan bulan Juli sampai dengan bulan Agustus 2020.Pembuatan bakso sapi substitusi ikan kembung dilakukan dilaboratorium penyelenggaraan makanan Universitas Muhadi Setiabudi Brebes. 
Penelitian analisis uji hedonik dilakukan di MI Muhammadiyah Sawojajar.Untuk uji kandungan protein dilaksakan di laboratorium BP2 MHP Semarang.Penelitian pada Uji organoleptik dengan panelis 25 untuk sampel populasinya mahasiswa Universitas Muhadi Setiabudi (UMUS) Brebes yang diantaranya adalah aroma, warna, rasa , dan tekstur pada baso ikan kembung...Untuk Kriteria inklusi dan eksklusinya dalam penelitian ini adalah panelis tidak terlatih sebanyak 25 mahasiswa, kriteria panelinya adalah, tidak sakit/tidak enak badan, dan bersedia menjadi panelis, kemudian bisa untuk bekerjasama.Variabel dalam penelitian ini terdiri dari dua macam, yaitu variabel kimia dan variabel sensori. Variabel kimianya yaitu Kadar protein, Variabel sensori berupa uji kesukaan yaitu Aroma, Rasa, Warna dan Tekstur.

Data Variabel kimia didapat dianalisis menggunakan Uji kadar Protein dan analisis sensoris dengan menggunakan sidik ragam (ANOVA). Bila sidik ragam menunjukan pengaruh yang nyata antar perlakuan $(\mathrm{P}<0,25)$ maka dilanjutkan dengan uji Duncan's New Multiple Test yang disingkat DMRT. Data yang sudah diperoleh dari penulusuran menggunakan dokumentasi dan hasil pengujian laboratorium akan diolah dan disajikan secara sistematis, beradasrkan rumusan masalah penelitian inikemudian akan dianalisis dan dibandingkan dengan teori-teori yang terkait. Untuk memudahkan dan mempercepat proses pengolahan data, penulis memakai komputerisasi dan menggunakan program SPSS versi 22, kemudian data yang telah dianalisis disajikan dalam bentuk tabel dan narasi, pada Kadar air yang nantinya akan dianalisis memakai metode oven. Cawan yang dipakai dioven dahulu selama kurang lebih 2 jam pada suhu 105 OC, yang selanjutnya didinginkan pada eksikator selama $1 / 2$ jam, kemudian baru ditimbang (a). Sampel kemudian ditimbang lagi (b), berikutnya cawan yang isinya sampel di oven dikeringkan lagi pada suhu 105 0C sampai 8 jam yang akhirnya diangin anginkan dalam eksikator $1 / 2$ jam kemudian ditimbang lagi .

\section{Analisi Kandungan Kadar Protein}

\section{HASIL DAN PEMBAHASAN}

Hasil analisis ragam pengaruh proporsi daging sapi dengan ikan kembung proporsi P1.80\%:20\%, P2.60\% : 40\% dan P3.40\%:60\% terhadap variabel kimia bakso sapi substitusi ikan kembung disajikan pada tabel 1 .

Tabel 1 Hasil Analisis Ragam Berdasarkan Kadar Protein Bakso Daging Sapi Substitusi Ikan Kembung

\begin{tabular}{ccccc}
\hline \multicolumn{5}{c}{ Pengulangan } \\
\hline Perlakuan & $\mathbf{1}$ & $\mathbf{2}$ & $\mathbf{3}$ & Rata-rata \\
\hline P1 & $11,31 \%$ & $11,40 \%$ & $12,17 \%$ & $11,62 \%$ \\
\hline P2 & $11,36 \%$ & $12,06 \%$ & $11,37 \%$ & $11.59 \%$ \\
\hline P3 & $11,93 \%$ & $11,44 \%$ & $12,03 \%$ & $11,80 \%$ \\
\hline nilai P (sig) & & & & 0,806 \\
\hline
\end{tabular}

Keterangan : P1 $80 \%$ perbandingan proporsi daging sapi dengan $20 \%$ Ikan kembung. P2 ,60\% perbadingan proporsi daging sapi dengan 40\% ikan kembung P3 perbandingan proporsi ,40\% daging sapi dan 60\% ikan kembung dengan Dengan nilai $\mathrm{P}$ (sig) 0,806 artinya $\mathrm{P}>0,05$ tidak terdapat pengaruh nyata

Kadar protein pada perlakuan P1, P2, P3 berturut-turut yaitu 11,62\%, 11,59\% dan $11,80 \%$. Menunjukan rata-rata kadar protein bakso berkisar antara 11,59\%-11,80\% . Hasil uji protein menunjukkan bahwa kandungan kadar protein pada bakso perlakuan daging sapi dengan ikan kembung paling tinggi pada perlakuan P3 (60\%) ikan kembung, dengan rata-rata 11,80\%. Hal ini menujukan semakin banyak proporsi ikan kembung maka akan semakin tinggi kandungan kadar protein pada bakso yang dihasilkan. Hal ini disebabkan kandungan protein pada ikan kembung yaitu 22,0 gr sedangkan kandungan protein pada daging sapi sebesar 18,8 gr,[14] sedangkan kadar protein terendah pada bakso perlakuan P2 dengan proporsi daging sapi (60\%). Bakso daging sapi substitusi ikan kembung yang dihasilkan memenuhi standar SNI protein. 


\section{Uji Hedonik (Tingkat Kesukaan)}

Analisis Uji Hedonik (Tingkat Kesukaan) dilakukan di MI Muhammadiyah Sawojajar dengan bantuan 20 panelis anak-anak yang berusia 11-12 th . Uji hedonik di lakukan meliputi: Aroma, rasa, warna dan Tekstur. Adapun hasil analisis uji statistik dapat dilihat pada tabel 2:

Tabel 2 Analisis Ragam Berdasarkan Uji Hedonik

\begin{tabular}{ccccc}
\hline \multirow{2}{*}{ Perlakuan } & \multicolumn{4}{c}{ Rerata Uji Hedonik } \\
\cline { 2 - 5 } & Aroma & Rasa & Warna & Tekstur \\
\hline P1 & $2,7^{\mathrm{a}}$ & $3,4^{\mathrm{a}}$ & $2,9^{\mathrm{a}}$ & $2,9^{\mathrm{a}}$ \\
\hline P2 & $3,0^{\mathrm{b}}$ & $3,4^{\mathrm{ab}}$ & $3,2^{\mathrm{ab}}$ & $3,2^{\mathrm{ab}}$ \\
\hline P3 & $3,2^{\mathrm{b}}$ & $3,3^{\mathrm{b}}$ & $3,2^{\mathrm{b}}$ & $3,1^{\mathrm{b}}$ \\
\hline Nilai P ( sig) & 0,001 & 0,072 & 0,050 & 0,048 \\
\hline
\end{tabular}

Keterangan : P1 perbandingan proporsi Daging Sapi 80\% dan 20\% Ikan kembung P2 proporsi Daging sapi $60 \%$ dan 40\% Ikan kembung. P3 proporsi Daging sapi 40\% dan Ikan kembung 60\%. Angka yang diikuti dengan huruf superscript berbeda (a, b, c, d) menunjukkan beda nyata.

1. Aroma

Aroma pada perlakuan P1, P2, P3 berturut-turut yaitu 2,7, 3,0 dan 3,2 Menunjukan ratarata bakso berkisar antara 2-3. Hasil uji kesukaan dengan indikator aroma menunjukan bahwa nilai aroma pada bakso perlakuan daging sapi dengan ikan kembung paling tinggi pada perlakuan P3 (60\%) ikan kembung, dengan rata-rata penilaian pada aroma yaitu 3,2 Berdasarkan tabel 2 bahwa semakin tinggi proporsi ikan kembung yang ditambahkan maka rerata nilai aroma semakin tinggi. Hal ini disebabkan didalam otot ikan kembung mengandung zat trimetillamin oksida atau TMAO, terpecah dan terdekomposisi menghasilkan trimetilamina dan dimetillamina campuran kedua rombakan amina menghasilkan bau yang amis atau anyir khas pada ikan sehingga dapat mempengaruhi aroma pada bakso yang dihasilkan. Hasil One-way ANOVA penambahan ikan kembung 20\% 40\% dan 60\%, berpengaruh secara signifikan terhadap aroma bakso yang ditunjukan nilai $\mathrm{P}(\mathrm{sig})$ : 0,001 kurang dari $(\mathrm{P}>0,05)$. Tabel 2 menunjukan pengaruh yang nyata antar perlakuan dengan nilai $\mathrm{P}<0,25)$ maka dilanjutkan dengan uji Duncan's New Multiple Test yang disingkat DMRT dengan tiga perlakuan dan 3 kali ulangan dengan proposi daging sapi P1. 80\%, P2.60\%.P3 40\% dan ikan kembung P1. 20\%, P2, 40\% dan P3.60\%. Berdasarkan uji DMRT diperoleh hasil P1 berbeda dengan P2 dan P3, sedangkan untuk P2 dan P3 memiliki kesamaan

Pada penelitian ini ikan kembung memberikan pengaruh terhadap aroma bakso daging sapi substitusi ikan kembung. Aroma bakso diperoleh dari campuran daging sapi dan ikan kembung serta bahan pendukung lainya. Penilaian untuk aroma pada baso sapi substitusi ikan kembung adalah penilaian yang berdasarkan dari indera pembau/hidung. ini dikarenakan pada setiap individu masing-masing memiliki perbedaan penciuman, walaupun mereka dapat membedakan aroma namun setiap orang memiliki kesukaan yang berbeda. Indera penciuman sangat sensitif terhadap bau dan timbulnya bau lebih kurang 0,8 detik kecepatanya. Kepekaan indera penciuman ini diperkirakan berkurang pada bertambahnya umur selama satu tahun.

Uji kesukaan terhadap aroma pada bakso substitusi ikan kembung menunjukan bahwa memberikan pengaruh nyata terhadap tingkat kesukaan panelis pada aroma. Aroma adalah merupakan yang berperan penting untuk hasil penerimaan terhadap produk produk jajan/ makanan setelah warna, sama halnya denga produk daging sapi seperti olahan bakso yang diberikan dari panelis pada bakso hasil substitusi daging sapi dengan ikan kembung dengan rentang nilai rata-rata 3 seperti yang dilihat pada tabel.2 yang artinya panelis suka pada aroma bakso hasil substitusi daging sapi dengan ikan kembun. 


\section{Rasa}

Rasa pada perlakuan P1, P2, P3 berturut-turut yaitu 3,4, 3,4 dan 3,3 Menunjukan ratarata bakso berkisar antara 3. Hasil uji kesukaan dengan indikator rasa menunjukan bahwa nilai rasa pada bakso perlakuan daging sapi dengan ikan kembung paling tinggi pada perlakuan P1 dan P2, P1(80\%) daging sapi (20\%) ikan kembung, P2 (60\%) daging sapi dengan (40\%) ikan kembung dengan rata-rata penilaian pada rasa yaitu 3. Hasil analisis uji ragam menunjukan bahwa proporsi daging sapi dengan ikan kembung tidak ada pengaruh terhadap rasa pada bakso. Hal ini disebabkan karena daging sapi mengandung asam stearat, asam oleat dan asam palmiat sehingga menghasilkan rasa yang sangat gurih terhadap bakso yang dihasilkan. Tabel 2 menunjukan bahwa kombinasi perlakuan antara proporsi daging sapi dengan ikan kembung tidak berpengaruh nyata terhadap rasa gurih pada bakso. Nilai rasa gurih pada bakso berkisar antara 3,4 (sangat gurih ) sampai 3,3 (gurih). Kombinasi perlakuan P1,P2 dan P3 memiliki nilai rasa sangat gurih cenderung tinggi yaitu 3,3-3,4. Semakin tinggi proporsi daging sapi ada kecenderungan nilai rasa gurih semakin tinggi. Hal tersebut disebabkan rasa daging sapi yang khas. Berdasarkan tabel 2 hasil uji One-way ANOVA ikan kembung (20\%, 40\% dan 60\%) tidak berpengaruh secara signifikan terhadap rasa bakso yang ditunjukan nilai $\mathrm{P}=0,072(\mathrm{P}<0,05)$ yang artinya tidak ada hubungan proporsi ikan kembung dengan mutu hedonik atau uji kesukaan rasa.

3. Warna

Warna pada perlakuan P1, P2, P3 berturut-turut yaitu 2,9, 3,2 dan 3,1 Menunjukan ratarata bakso berkisar antara 2-3. Hasil uji kesukaan dengan indikator warna menunjukan bahwa nilai warna pada bakso perlakuan daging sapi dengan ikan kembung paling tinggi pada perlakuan P2 dan P3, P1(60\%) daging sapi (40\%) ikan kembung, P2 (40\%) daging sapi dengan $(60 \%)$ ikan kembung dengan rata-rata penilaian pada warna yaitu 3. Hasil analisis menunjukan bahwa proporsi daging sapi dengan ikan kembung ada pengaruh terhadap warna pada bakso. tabel. 2 menunjukan bahwa semakin tinggi proporsi ikan kembung yang ditambahkan maka rerata nilai warna semakin tinggi. Hal ini diduga karena adanya reaksi Maillard reaksi-reaksi pada daging ikan tingginya kandungan mineral pada ikan kembung menyebabkan warna produk semakin gelap sehingga dapat mempengaruhi warna pada bakso yang dihasilkan. Hasil One-way ANOVA penambahan ikan kembung 20\%,40\% dan 60\%, berpengaruh secara signifikan terhadap aroma bakso yang ditunjukan nilai $\mathrm{P}(\mathrm{sig})$ : 0,050 kurang dari $(\mathrm{P}>0,05)$. Tabel.2 menunjukan pengaruh yang nyata antar perlakuan dengan nilai $\mathrm{P}<0,25$ ) maka dilanjutkan dengan uji Duncan's New Multiple Test yang disingkat DMRT dengan hasil pada tabel.2 dengan tiga perlakuan dan 3 kali ulangan dengan proposi daging sapi P1. 80\%, P2.60\%.P3 40\% dan ikan kembung P1. 20\%, P2, 40\% dan P3.60\%. Berdasarkan uji DMRT diperoleh hasil P1 dan P2 memiliki kesamaan dan P2 dan P3 diperoleh hasil yang sama, sedangkan untuk P1 dan P3 berbeda.

Salah satu faktor utama untuk tampilan suatu bahan pangan adalah warna yang akan dinilai sebelum rasa dan nilai gizi. Bahan pangan yang di nilai bergizi, enak dan teksturnya sangat baik tidak akan dimakan apabila warna yang dilihat tidak enak dipandang atau tidak sedap dipandang hal ini akan memberi kesan yang telah menyimpang dari warna sebenarnya.[15] Warna makanan yang menarik, cantik dan nampak alamiah dapat meningkatkan cita rasa makanan itu sendiri .Fungsi dari warna pada suatu makanan sangatlah utama dan penting, karena dapat membangkitkan selera untuk makan. Warna makanan dapat menandakan rasa. Bila suatu makanan menyimpang dari warna yang umumnya, tentunya makanan tersebut tidak akan dipilih oleh konsumen walaupun sebenarnya makanan itu masih baik kondisinya. walaupun demikian, warna juga tidak selalu identik dengan suatu rasa tertentu. Hasil uji penilaianyang dilihat pada tabel.2, bisa disimpulkan dari warna tergolong disukai. Hal ini tentu sebagai salah satu faktor 
utama untuk anak-anak supaya tertarik untuk mengonsumsi bakso dari proporsi daging sapi dan ikan kembung.

\section{Tekstur}

Tekstur pada perlakuan P1, P2, P3 berturut-turut yaitu 2,9, 3,2 dan 3,1 Menunjukan ratarata bakso berkisar antara 2-3. Hasil uji kesukaan dengan indikator tekstur menunjukan bahwa nilai tekstur pada bakso perlakuan daging sapi dengan ikan kembung paling tinggi pada perlakuan P2 (60\%) daging sapi (40\%) ikan kembung, dengan rata-rata penilaian pada rasa yaitu 3. Tekstur merupakan salah satu faktor penentu terhadap tingkat kesukaan panelis, karena konsumen menyukai produk bakso terutama karena teksturnya yang kenyal, kekenyalan bakso erat kaitanya dengan penggunaan es batu fungsi es batu adalah sebagai pembentuk tekstur menjadi halus dan lebih kenyal es batu juga berguna untuk membantu melarutkan semua bahan jika dimakan atau dikunyah terasa kenyal dan rasanya enak. Sebenarnya belum ada ketentuan ataupun standart tersebut, kriteria ini dapat dijadikan sebagai penilaian kualitas.Berdasarkan tabel.2 hasil uji One-way ANOVA menujukan bahwa uji tekstur ada pengaruh terhadap penambahan ikan kembung pada bakso sapi hal inidapat dilihat pada nila $\mathrm{P}(\mathrm{sig})=0,048$ yang artinya $(\mathrm{P}>0,05)$. Penilaian tekstur bakso merupakan penilaian yang berdasarkan indera peraba. Tekstur makanan berkaitan dengan sensasi sentuhan. Mengandung satu produk dapat memberi gagasan apakah suatu produk tersebut kenyal, tidak kenyal atau sangat tidak kenyal.Tabel. 2 menunjukan pengaruh yang nyata antar perlakuan dengan nilai $\mathrm{P}<0,25$ ) maka dilanjutkan dengan uji Duncan's New Multiple Test yang disingkat DMRT dengan hasil pada tabel 4.2 dengan tiga perlakuan dan 3 kali ulangan dengan proposi daging sapi P1. 80\%, P2.60\%.P3 40\% dan ikan kembung P1. 20\%, P2, 40\% dan P3.60\%. Berdasarkan uji DMRT diperoleh hasil P1 dan P2 memiliki kesamaan dan P2 dan P3 diperoleh hasil yang sama, sedangkan untuk P1 dan P3 berbeda.

Dari penelitian bakso substitusi daging sapi dan ikan kembung secara sensoris diketahui bahwa, Sebagaimana terlihat pada tabel.2 secara umum tingkat kesukaan panelis terhadap parameter kekenyalan bakso berkisar rentang rerata 2,9-3,2, ini berarti panelis cenderung suka pada kekenyalan bakso yang dihasilkan.

\section{Kadar Air}

Kadar air adalahsalah satu faktor yang penting pada bahan pangan karena kadar air akan mempengaruhi daya simpan pada bahan pangan tersebut [16]. Hasil uji kadar air bakso ikan kembung akan ditampilkan dalam Tabel 3 berikut:

Tabel 3 Hasil Analisis Data Kadar Air

\begin{tabular}{|c|c|c|c|c|c|}
\hline \multirow[t]{2}{*}{ Perlakuan } & \multicolumn{3}{|c|}{ Pengulangan } & \multirow[b]{2}{*}{ Rata-rata } & \multirow[b]{2}{*}{ Nilai P } \\
\hline & 1 & 2 & 3 & & \\
\hline P1 & 1,72 & 1,73 & 1,69 & 1,73 & 0,386 \\
\hline $\mathbf{P 2}$ & 1,69 & 1,66 & 1,64 & 1,64 & \\
\hline P3 & 1,68 & 1,66 & 1,65 & 1,63 & \\
\hline
\end{tabular}

Keterangan : P1 perbandingan proporsi Daging Sapi 80\% dan 20\% Ikan kembung P2 proporsi Daging sapi $60 \%$ dan 40\% Ikan kembung. P3 proporsi Daging sapi 40\% dan Ikan kembung 60\%.

Kadar air bakso ikan kembung untuk perlakuan P1 kadar airnya yang tertinggi adalah $1,73 \%$. Ini adanya menggunakan bahan dasar yang lebih banyak dibandingkan dengan perlakuanperlakuan lainnya. pada P3 memiliki kadar air sama yaitu 1,63. Karena Rendah kadar air pada P3 dikarenakan sebagian hilang pada saat proses pengukusan bakso serta penggunaan bahan dasar yang lebih sedikit dibandingkan dengan perlakuan-perlakuam yang lain. Berdasarakn hal ini 
sejalan dengan penelitian Rifqi (2017) yang menyatakan bahwa pengukusan dilakukan untuk meminimalisir kandungan air pada bahan pangan [17]. Hasil uji analisis ragam pengaruh proporsi daging sapi dengan ikan kembung proporsi P1.80\%:20\%, P2.60\% : 40\% dan P3.40\%:60\% tidak berpengaruh secara signifikan terhadap kadar airbaso ikan kembung, yang ditunjukan nilai $\mathrm{P}=$ 0,386 ( $\mathrm{P}>0,05)$. Kadar air mempengaruhi pada cita rasa dan teksturbakso dikarenakan kadar air yang masih tinggi mengakibatkan tumbuhnya mikroba pada bahan pangan hal ini dapat merusak dan menyebabkan tekstur lebih mudah lembek dan lebih berair. Fakor yang juga berperan penting pada penurunan kadar air yaitu pada saat penirisan bakso.

\section{KESIMPULAN}

Berdasarkan hasil penelitian yang telah dilakukan, diperoleh kesimpulan sebagai berikut Uji kesukaan proporsi daging sapi dan ikan kembung pada rasa tidak ada pengaruh bakso daging sapi substitusi ikan kembung terhadap daya terima sedangkan mutu hedonik pada aroma, warna dan tekstur berpengaruh terhadap bakso daging sapi substitusi ikan kembung. Tidak ada pengaruh proporsi daging sapi dengan ikan kembung untuk menghasilkan bakso sebagai makanan tinggi protein.

\section{SARAN}

Saran yang didapat adalah pentingnya untuk melakukan modifikasi bahan pangan khususnya bahan pangan ikan lokal untuk meningkatkan daya tarik masyarakat mengkonsumsi makanan yang bergizi untuk memperbaiki status gizi masyarakat, dengan membuat bakso dari daging sapi dan ikan kembung untuk menjadi jajanan yang aman dikonsumsi bagi anak-anak dengan menguji kandungan lainya seperti omega-3. Vitamin b6 pada ikan kembung.Diperlukan penelitian lebih lanjut mengenai baksoikan kembung untuk anak SD dengan menggunakan bahan lainya yang aman serta tinggi akan kandungan gizi lainya

\section{DAFTAR PUSTAKA}

[1]. Nalendrya et al 2016. Sosis ikan kembung sebagai pangan sumber Omega-3. Jurnal Aplikasi Teknologi Pangan. Vol 3, No 3.

[2]. Santoso, J.,Ling, F dan Handayani, R. (2011). Pengaruh pengkomposisian dan penyimpanan dingin terhadap perubahan karakteristik surimi ikan pari (trygon sp) dan ikan kembung (rastrelliger sp.) jurnal akuatika 2(2).

[3]. Irawan, S. 2009. Status Perikanan Ikan Kembung di Kabupaten Baru. Laporan Penelitian. Fakultas Perikanan dan Ilmu Kelautan. Universitas Brawijaya. Malang.

[4]. Almatsier S. (2009). Prinsip Dasar Ilmu Gizi. Jakarta: Gramedia Pustaka Utama.

[5]. Muctadi, D. 1989. Protein : Sumber-sumber dan Teknologi. Pusat Antar Universitas Pangan dan Gizi. Institut Pertanian Bogor, Bogor

[6]. Sunarya. 1993. Nilai gizi ikan dan pengolahanya menjadi sumber pangan yang bergizi. Makalah Seminar Mahasiswa Perikanan Universitas Juanda. Bogor.

[7]. Irawan, S. 2009. Status Perikanan Ikan Kembung di Kabupaten Baru. Laporan Penelitian. Fakultas Perikanan dan Ilmu Kelautan. Universitas Brawijaya. Malang.

[8]. Rajagukguk, Merlin. 2011. Pengaruh kombinasi pencampuran Tempe Kedelai (Glycine Max) dan tepung ikan kembung (Rastrelliger kanagurta L.) jantan kualitas Cookies. Thesis S1 Universitas Atmajaya Yogyakarta

[9]. Astuti E 2009. Pengaruh Jenis Tepung dan cara pemasakan Bakso dari surimi ikan hasil tangkap sampingan (HTS). Skripsi. Program Studi Teknologi Hasil Perikanan, Fakultas Perikanan dan Ilmu Kelautan. Institut Pertanian Bogor.

[10]. Thio, Sienny.2008. Persepsi Konsumen Terhadap Makanan Organik di Surabaya. Jurnal Manajemen Perhotelan 4(1):18-27.

[11]. Cindy Nafa Ferantika (2005). Karakteristik Fisiokimia Dan Organoleptik Bakso Ikan Kembung (Rastrelliger Kanaguarta) dengan Substitusi Wortel. 
[12]. Mahasiswa Ilmu Teknologi Pangan (2013) Karakteristik Organoleptik dan Kimia Bakso Ikan Kembung (Rastrelliger Kanaguarta) yang di Substitusi dengan Tepung Sagu (Metroxylon sago) Sebagai Bahan Pengisi

[13]. Angka Kecukupan Gizi (AKG). (2013). Tabel Angka Kecukupan Gizi 2013 Bagi Orang Indonesia. Tersedia dalam:http://gizi.depkes.go.id.

[14]. Kusnadi, D.,V.P. Bintaro dan A.N.Al-Baari. 2012. Daya Ikat Air Tingkat Kekenyalan dan Kadar Protein pada Bakso Kombinasi Daging Sapi dan Daging Kelinci. Jurnal Aplikasi Teknologi.Pangan . 1(2):28-31.

[15]. Gulendra I.W (2010). Pengertian Warna dan Tekstur. Jurnal Seni Rupa, 1:32-34

[16]. Yuniarti DR., Solikhin A., Fera M. (2020). Uji Organoletik Tepung Ampas Tahu dengan Variasi Lama Pengeringan. JIGK: Jurnal Ilmu Gizi dan Kesehatan. Volume 1 (2): 11-17.

[17]. Rifqi A M, 2017. Formulasi Nugget Tahu Pury (Nugget tapury) sebagai Alternatif. Institut Pertanian Bogor, V:22-30. 